\title{
Removal of crystal violet from water by magnetically modified activated carbon and nanomagnetic iron oxide
}

\author{
Soheila Hamidzadeh ${ }^{1}$, Marzieh Torabbeigi $i^{2^{*}}$ and Seyed Jamaleddin Shahtaheri ${ }^{3}$
}

\begin{abstract}
Magnetically modified activated carbon, which synthesized by nanomagnetic iron oxide, was used for fast and effective removal of Crystal Violet from aqueous solutions. The scanning electron microscopy (SEM) images of nano-adsorbent showed that the average sizes of adsorbent are less than $100 \mathrm{~nm}$. The various parameters, affecting on adsorption process, were examined including $\mathrm{pH}$ and temperature of dye solution, dose of adsorbent, and contact time. Then, thermodynamic parameters of sorption were calculated. Langmuir and Freundlich isotherms were used to fit the resulting data. Adsorption kinetics was consistent with a pseudo second order equation. Thermodynamic parameters of adsorption, $\Delta H^{0}$, and $\Delta S^{0}$ were calculated. Also, for further investigations, nano magnetic iron oxides was synthesized and used as adsorbent. Sorption capacities were depending on the temperature varied from 44.7 to $67.1 \mathrm{mg} / \mathrm{g}$ and from 12.7 to $16.5 \mathrm{mg} / \mathrm{g}$ for magnetically modified activated carbon and nanomagnetic iron oxide, respectively.
\end{abstract}

Keywords: Magnetically modified activated carbon, Crystal Violet, Langmuir isotherm, Freundlich isotherm, Nano magnetic iron oxide

\section{Introduction}

Large amounts of dyes are produced and applied in various industries. Small amounts of dyes (less than $1 \mathrm{ppm}$ for some dyes) are visible in water [1,2]. As the most of the dyes in wastewater are stable to light and oxidation and also resistant to aerobic digestion, they damage to the aquatic life [3].

Crystal Violet (CV) is a synthetic basic cationic dye used for various purposes including biological stain, dermatological agent, veterinary medicine, additive to poultry feed to inhibit propagation of mold, intestinal parasites, and textile dyeing industries etc. $[4,5]$. It is a mutagen, mitotic poison, and also proven potent carcinogen [6,7].

Various processes were developed for the dye removal from the wastewater including adsorption and biosorption [8-10], chemical and electrochemical oxidation [11-13], membrane separation process [14], photodegradation [15], etc.

\footnotetext{
* Correspondence: torabbeigi@gmail.com

${ }^{2}$ Faculty of Health, Safety and Environment, Shahid Beheshti University of Medical sciences, P. O. Box 16858-116, Tehran, Iran

Full list of author information is available at the end of the article
}

Magnetic separation techniques have found important applications in environmental technology. In adsorption processes, the magnetic adsorbent can be easily separated from solution after adsorption process [16]. The magnetizations of adsorbents such as peanut husks [17], sawdust [18], baker's yeast cells [19], activated coconut shell carbon [20] etc. were investigated for removal dyes and other concomitances. Since Activated carbon is one of most useful adsorbent for removal of dye, in this study, it was modified by nanomagnetic iron oxide for fast and effective removal of Crystal Violet. The SEM images indicated the sizes of adsorbent particles are in nano scales. Adsorbent efficiency in removal Crystal Violet was studied. The affecting parameters on adsorption process were examined. The thermodynamic and kinetic adsorption parameters of Crystal violet onto magnetically modified activated carbon were obtained while; they have not been reported in previous studies. In order to comparative studies, nanomagnetic iron oxide (that used for magnetization of activated carbon) were synthesized and used as adsorbent. 


\section{Materials and methods Reagents}

Activated charcoal was purchased from BDH Ltd Poole England. Crystal Violet dye was from Merck Darmstadt Germany. All other chemicals used in this study were of high purity and used without further purification. Double distilled water was used for all experiments.

\section{Adsorbent}

Magnetically modified activated carbon was synthesized with slightly modified procedure described in reference [21]. $1 \mathrm{~g}$ of activated charcoal was placed in contact with $150 \mathrm{ml}$ of sodium hydroxide $0.5 \mathrm{~mol} / \mathrm{l}$ for $30 \mathrm{~min}$ and mixed up by stirrer thoroughly. Then, it was heated to boiling. $50 \mathrm{ml}$ of solution containing Fe

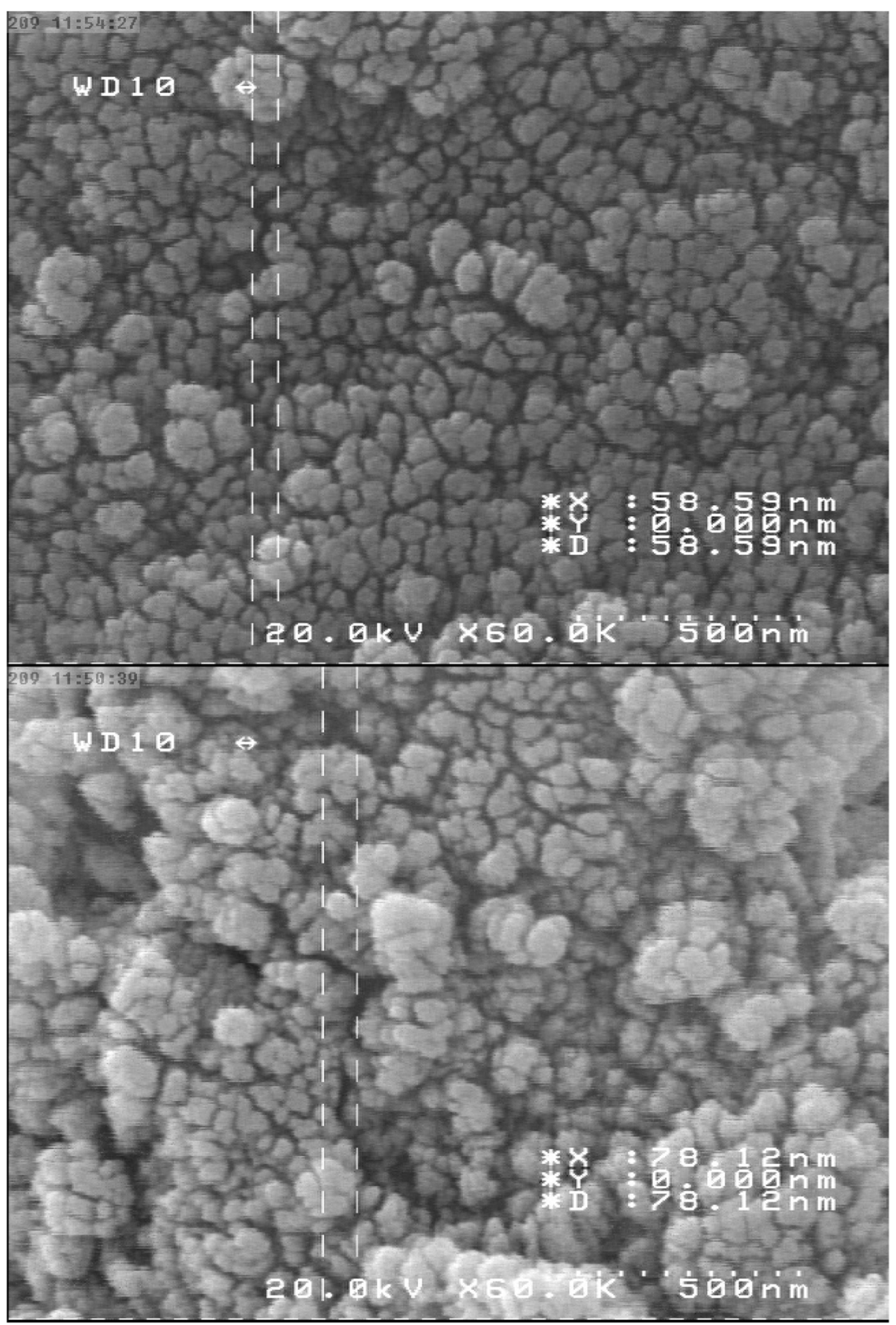

Figure 1 The SEM images of synthesized magnetically modified activated carbon. 


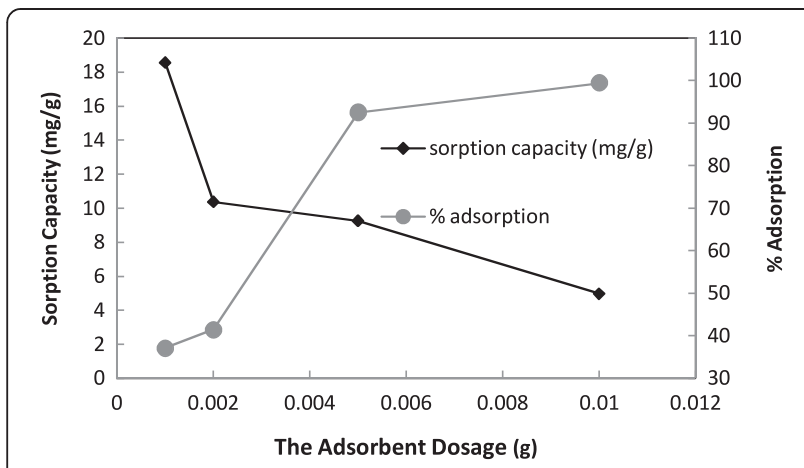

Figure 2 Effect of adsorbent dosage on adsorption percentage.

$\left(\mathrm{NO}_{3}\right)_{3} 0.2 \mathrm{M}$ and $\mathrm{FeSO}_{4} 0.1 \mathrm{M}$ was added quickly. The mixture was transferred into a distillation flask to reflux for two hours. Magnetically modified activated carbon was collected by magnet and then washed by water, methanol, and acetone several times to remove excess sodium hydroxide. It was then placed in oven at $80^{\circ} \mathrm{C}$ to drying for $12 \mathrm{~h}$. The scanning electron microscopy (SEM) images of magnetically modified activated carbon have been shown in Figure 1 indicated that the sizes of synthesized magnetic particles are less than $100 \mathrm{~nm}$.

\section{Adsorption procedure}

Batch adsorption experiments with $10 \mathrm{ml}$ of Crystal Violet solution (5 mg/l) were done for $1-10 \mathrm{mg}$ of adsorbent, 1 to 10 min contact times, 3-9 pHs, and at 20, 30 and $40^{\circ} \mathrm{C}$.

pHs of solutions were adjusted by expected values of nitric acid and sodium hydroxide solutions. Analysis of

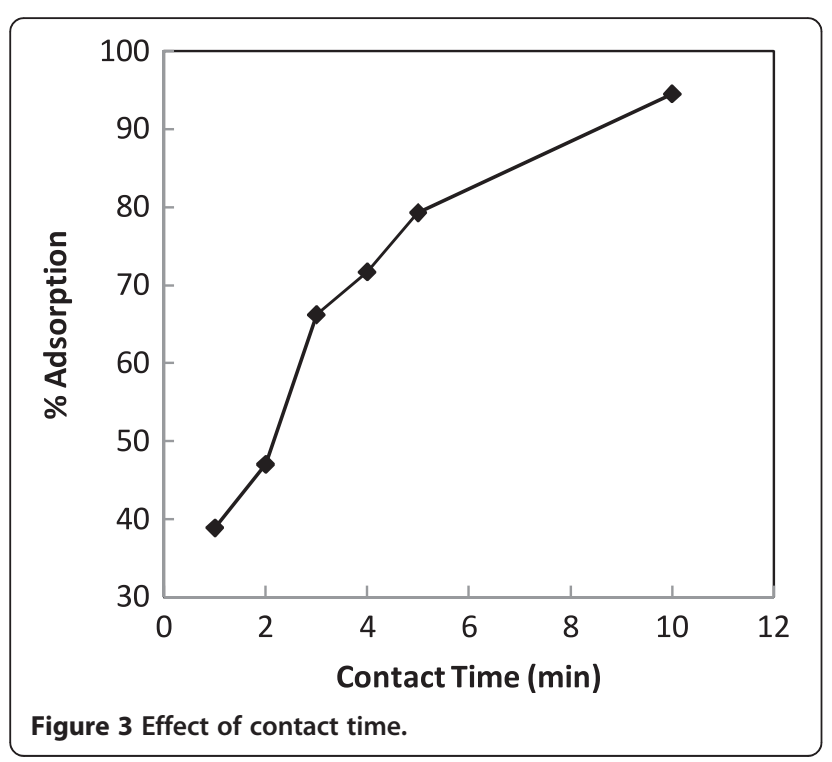

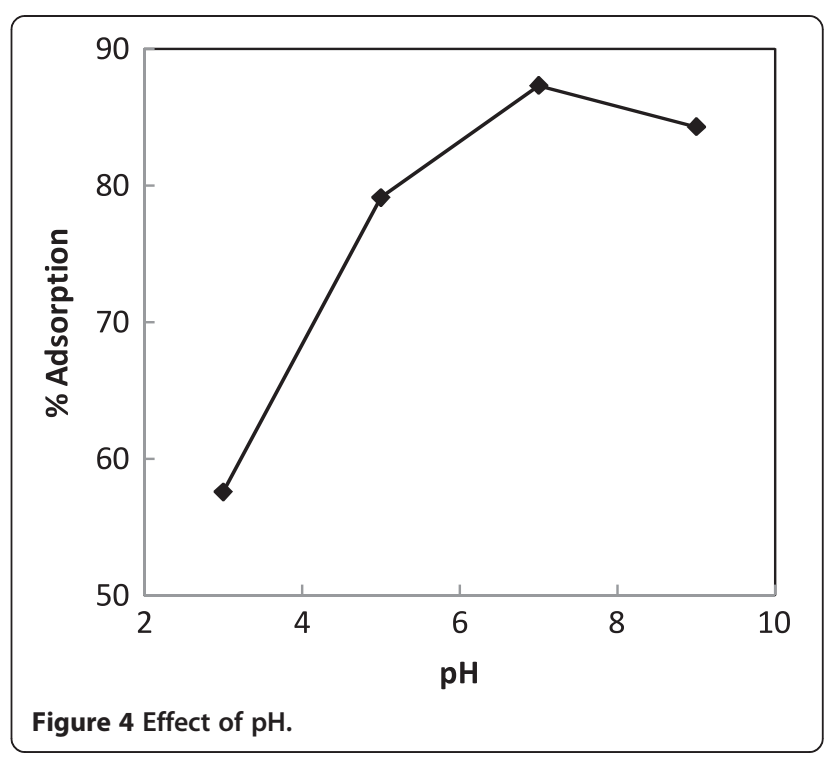

dye concentration was carried out by UV-vis spectrophotometer in $593 \mathrm{~nm}$ wavelength.

Percentage of dye removal from solution was calculated by the following equation:

$$
\operatorname{Removal}(\%)=\frac{C_{0}-C_{i}}{C_{0}} \times 100
$$

$\mathrm{C}_{0}$ and $\mathrm{C}_{\mathrm{i}}$ are initial and final concentration of Crystal Violet solutions, respectively. The following formula is used to calculate the amount of dye adsorbed by the adsorbent:

$$
q_{e}=\left(C_{0}-C_{e}\right) \times \frac{v}{w}
$$

Where $\mathrm{q}_{\mathrm{e}}$ is adsorption capacity (mg of adsorbed dye per $g$ of adsorbent), $C_{e}$ is equilibrium concentration of

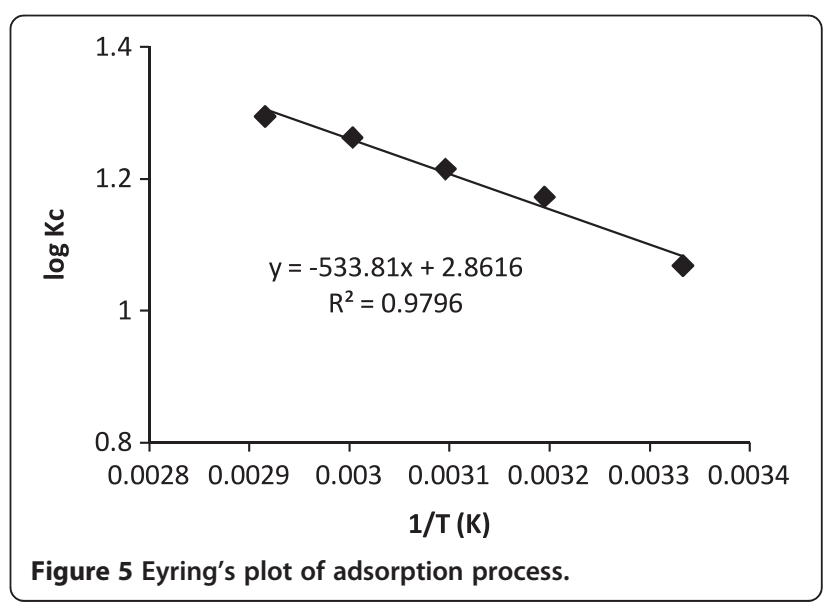


Table 1 The thermodynamic parameters of adsorption of Crystal Violet on magnetically modified activated carbon

\begin{tabular}{llll}
\hline Temp. (K) & $\boldsymbol{\Delta} \mathbf{G}^{\mathbf{0}}(\mathbf{k J} / \mathbf{m o l})$ & $\Delta \mathbf{S}^{\mathbf{0}}(\mathbf{k J} / \mathbf{m o l} . \mathbf{K})$ & $\Delta \mathbf{H}^{\mathbf{0}}(\mathbf{k J} / \mathbf{m o l})$ \\
\hline 300 & -6.14 & 0.055 & 10.22 \\
313 & -7.03 & & \\
323 & -7.51 & & \\
333 & -8.05 & & \\
343 & -8.50 & & \\
\hline
\end{tabular}

dye $(\mathrm{mg} / \mathrm{l}), \mathrm{v}$ is the volume of the solution (l) and $\mathrm{w}$ is the mass of adsorbent $(\mathrm{g})$.

\section{Kinetic study}

Pseudo-first and pseudo-second order models were applied for the adsorption kinetic studies. The first order rate equation of Lagergren was used for the adsorption:

$$
\log \left(q_{e}-q_{t}\right)=\log \left(q_{e}\right)-\frac{k_{1}}{2.303} t
$$

Where $\mathrm{q}_{\mathrm{e}}$ and $\mathrm{q}_{\mathrm{t}}$ are masses of dye adsorbed at equilibrium and at time $\mathrm{t}\left(\mathrm{mg} \mathrm{g}^{-1}\right)$, respectively, and $\mathrm{k}_{1}$ is the first-order reaction rate constant $\left(\mathrm{min}^{-1}\right)$. Pseudo-second order equation was used based on Ho-Mckay equation:

$$
\frac{t}{q_{t}}=\frac{1}{k_{2} q_{e}^{2}}+\frac{1}{q_{e}} t
$$

Where $k_{2}$ is the second order reaction rate equilibrium constant $\left(\mathrm{g} \mathrm{mg}^{-1} \mathrm{~min}^{-1}\right)$.

\section{Result and discussion Optimization The adsorbent dosage}

As the dose of adsorbent can strongly affect the sorption capacity, the adsorption procedure was done with varied dose of adsorbent (1-10 mg). Obtained results shown in
Figure 2 indicated that, increasing amount of the adsorbents increases the contact surface area and exchangeable sites, and then increases the percent removal of dye.

\section{The contact time}

The contact time is one of the important factors affecting on batch adsorption process, therefore, contact time from 1 to 10 min was studied for removal of dye. Resulting data were shown in Figure 3. This synthesized nano magnetic adsorbent removed Crystal Violet very fast, so that, more than $90 \%$ of dye was removed in $10 \mathrm{~min}$ and adsorption process attains saturation at this time.

\section{pH of Crystal Violet solution}

To study the effect of $\mathrm{pH}$ on the adsorbent, the range of $\mathrm{pH}$ adjusted between 3 and 9. The experimental date indicated that, the removal of dye was so effective at $\mathrm{pH}$ 9. Figure 4 shows the effect of $\mathrm{pH}$ on removal of Crystal Violet. Cationic dyes like Crystal Violet were adsorbed on activated carbon surface at alkaline pHs [22,23].

\section{Temperature of dye solution}

Dye removal was examined at different temperatures range started from $27^{\circ} \mathrm{C}$ (as ambient temperature) to $70^{\circ} \mathrm{C}$. $10 \mathrm{ml}$ of dye solution $5 \mathrm{mg} / \mathrm{l}$ was contacted to $0.01 \mathrm{~g}$ of magnetically modified activated carbon for $5 \mathrm{~min}$ at $\mathrm{pH} 5$ at $27,40,50,60$, and $70^{\circ} \mathrm{C}$.

Thermodynamic parameters, $\Delta S^{0}$ and $\Delta H^{0}$ were calculated from Eyring's plot; log Kc versus 1/T (Figure 5).

$$
\begin{aligned}
& \log K_{C}=\frac{\Delta S^{0}}{2.303 R}-\frac{\Delta H^{0}}{2.303 R} \frac{1}{T} \\
& K_{C}=\frac{C_{a d}}{C_{e}}
\end{aligned}
$$

Where $K_{C}$ is the equilibrium constant, $C_{a d}$ and $C_{e}$ are the equilibrium concentrations of the dyes on the
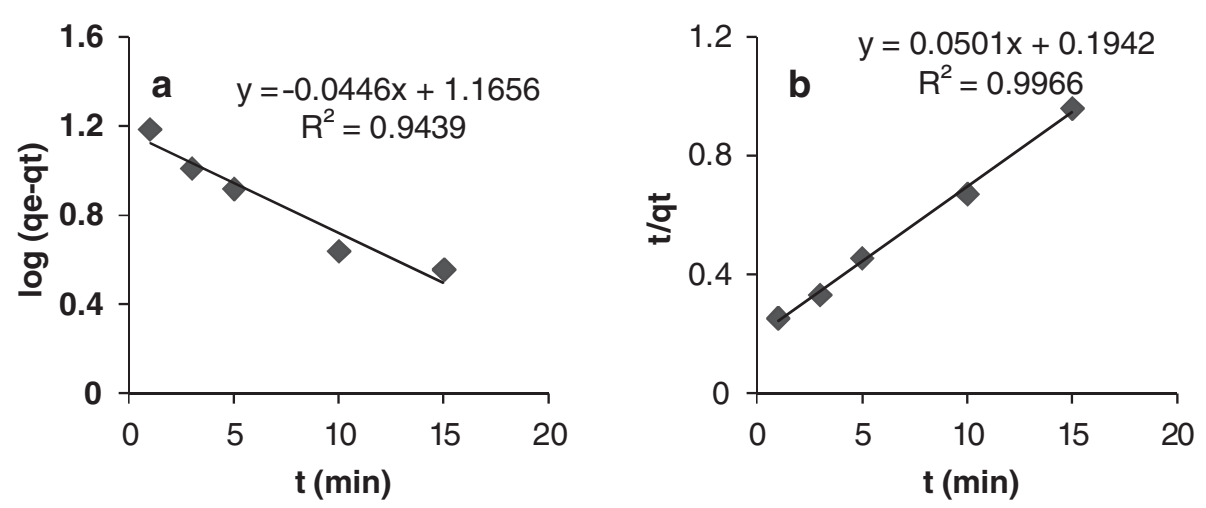

Figure 6 The fitting data of adsorption procedure by (a) pseudo-first order and (b) second order equations. 
Table 2 The rate constants and linear regressions of First order and Second order for adsorption of Crystal Violet on magnetically modified activated carbon and nanomagnetic iron oxide

\begin{tabular}{llllll}
\hline Adsorbent & \multicolumn{2}{l}{ First order } & & \multicolumn{2}{l}{ Second order } \\
\cline { 2 - 3 } & $\mathbf{k}_{\mathbf{1}}\left(\mathbf{m i n}^{-\mathbf{1}}\right)$ & $\mathbf{R}^{\mathbf{2}}$ & & $\mathbf{k}_{\mathbf{2}}\left(\mathbf{g ~ m g}^{\mathbf{- 1}} \mathbf{~ m i n}^{\mathbf{- 1}}\right)$ & $\mathbf{R}^{\mathbf{2}}$ \\
\hline $\begin{array}{l}\text { Magnetically modified } \\
\begin{array}{l}\text { activated carbon } \\
\text { Nanomagnetic }\end{array}\end{array}$ & 0.103 & 0.944 & 0.752 & 0.997 \\
$\begin{array}{l}\text { Nan oxide } \\
\text { iron }\end{array}$ & 0.230 & 0.901 & $1.38 \times 10^{-2}$ & 0.962 \\
\hline
\end{tabular}

adsorbent and in solution, respectively, $\mathrm{T}$ is the temperature in Kelvin and $\mathrm{R}$ is gas constant. Then, $\Delta \mathrm{G}^{0} \mathrm{~S}$ in different temperature were determined by:

$$
\Delta G^{0}=-2.303 R T \log K_{C}
$$

Obtained thermodynamic parameters are presented in Table 1 . The negative values of free energy $\left(\Delta G^{0}\right)$ indicate the feasibility of dye removal and spontaneous nature of adsorption process. Value of $\Delta \mathrm{H}^{0}$ confirms that the adsorption of Crystal Violet on magnetically modified activated carbon is endothermic process. The positive $\Delta S^{0}$ demonstrate the affinity of Crystal Violet on to nano adsorbent.

\section{Kinetic study}

In order to determine the kinetic of adsorption, the results were evaluated by equations (3) and (4) that related to the pseudo-first order and second order kinetics, respectively. Figure $6 \mathrm{a}$ and $\mathrm{b}$ show the fitting data by pseudo-first order and second order equations. The rate constants and linear regressions $\left(R^{2}\right)$ were reported in Table 2. The results indicated that, the adsorption of Crystal Violet on magnetically modified

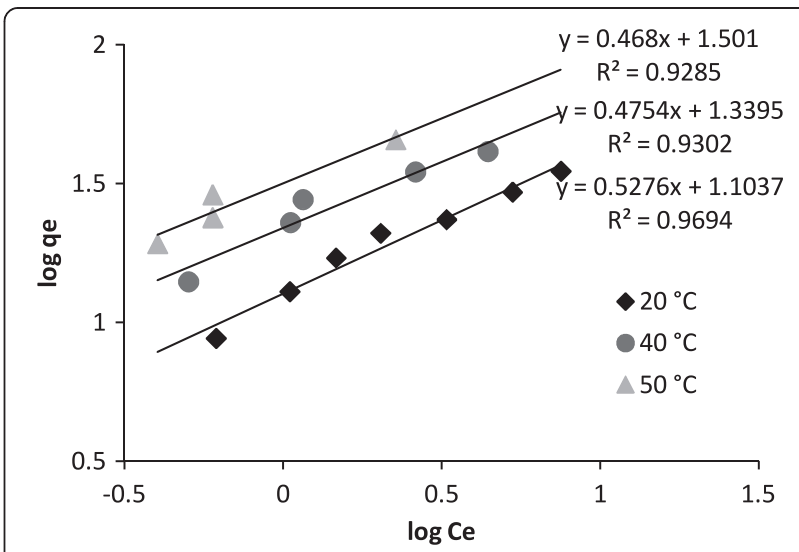

Figure 8 Freundlich isotherms in various temperatures.

activated carbon has been described by pseudo-second order equation.

In order to perform further investigation, nanomagnetic iron oxide was synthesized as similar as described in experimental section, without any addition of activated carbon. In the same conditions, nanomagnetic iron oxide was used as adsorbent. The kinetic results shown in Table 2 indicated that, the kinetic of adsorption was the same as magnetically modified activated carbon with lower rate constant $\left(\mathrm{k}_{2}\right)$.

\section{Adsorption isotherms}

Adsorption isotherms are important to describe the adsorption mechanism and to determine the maximum adsorption capacity and also to consider the feasibility of the application process. Langmuir and Freundlich equations were used to study the adsorption isotherms. The Langmuir model is describing the monolayer adsorption onto a surface with a finite

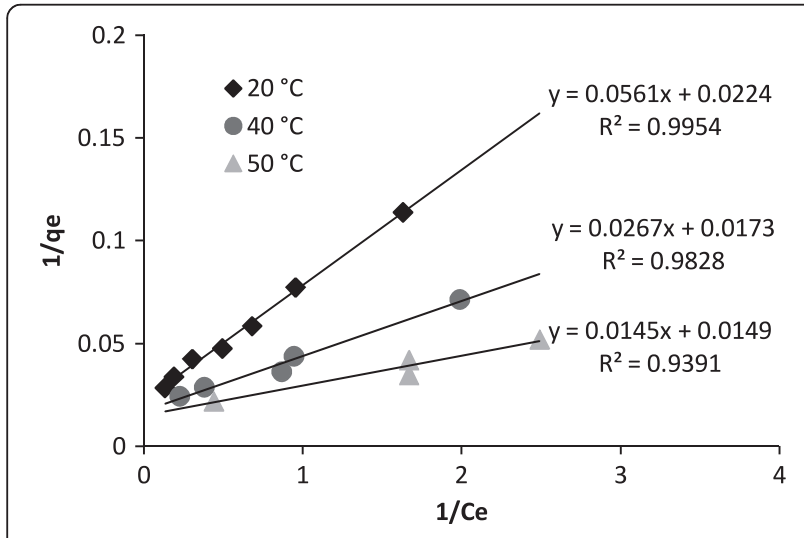

Figure 7 Langmuir isotherms in various temperatures.
Table 3 The parameters of Langmuir and Freundlich isotherms at different temperatures for adsorption of Crystal Violet on magnetically modified activated carbon and nanomagnetic iron oxide

\begin{tabular}{|c|c|c|c|c|c|c|c|}
\hline \multirow[t]{2}{*}{ Adsorbent } & \multirow{2}{*}{$\begin{array}{l}\text { Temp. } \\
\left({ }^{\circ} \mathrm{C}\right)\end{array}$} & \multicolumn{3}{|c|}{ Langmuir } & \multicolumn{3}{|c|}{ Freundlich } \\
\hline & & $\mathrm{q}_{\max }$ & $\mathrm{K}_{\mathrm{L}}$ & $\mathrm{R}^{2}$ & $\mathrm{~K}_{\mathrm{F}}$ & $\mathrm{n}$ & $\mathrm{R}^{2}$ \\
\hline \multirow{3}{*}{$\begin{array}{l}\text { Magnetically modified } \\
\text { activated carbon }\end{array}$} & 20 & 44.7 & 0.40 & 0.995 & 12.7 & 1.90 & 0.969 \\
\hline & 40 & 57.8 & 0.65 & 0.983 & 21.9 & 2.10 & 0.930 \\
\hline & 50 & 67.1 & 1.03 & 0.939 & 31.7 & 2.14 & 0.929 \\
\hline \multirow{3}{*}{$\begin{array}{l}\text { Nanomagnetic } \\
\text { iron oxide }\end{array}$} & 20 & 12.7 & 0.045 & 0.956 & 8.2 & 1.02 & 0.918 \\
\hline & 40 & 14.5 & 0.047 & 0.982 & 10.1 & 1.03 & 0.935 \\
\hline & 50 & 16.5 & 0.051 & 0.970 & 15.5 & 1.19 & 0.952 \\
\hline
\end{tabular}


number of identical sites. Linear form of Langmuir isotherm is given by:

$$
\frac{1}{q_{e}}=\frac{1}{q_{\max } K_{L} C_{e}}+\frac{1}{q_{\max }}
$$

Where $\mathrm{q}_{\max }(\mathrm{mg} / \mathrm{g})$ is the maximum adsorption capacity and $\mathrm{K}_{\mathrm{L}}$ is a constant factor related to the energy. The variations of $1 / \mathrm{q}_{\mathrm{e}}$ at different temperatures are plotted versus $1 / C_{e}$ in Figure 7.

The Freundlich model is based on the sorption onto a heterogeneous surface. The linear expression of Freundlich equation is as follow:

$$
\log \left(q_{e}\right)=\log \left(K_{F}\right)+\frac{1}{n} \log \left(C_{e}\right)
$$

Where $K_{F}$ and $n$ are the Freundlich constants, being indicators of adsorption capacity and adsorption intensity, respectively. $\log \mathrm{q}_{\mathrm{e}}$ at different temperatures versus $\log C_{e}$ is plotted in Figure 8.

The regression coefficients and model parameters for Langmuir and Freundlich isotherms are tabulated in Table 3. The regression coefficients indicated that the data are better fitted by the Langmuir model. The maximum sorption capacity $\left(\mathrm{q}_{\max }\right)$ and intensity of sorption $\left(\mathrm{K}_{\mathrm{L}}\right)$ increased by arising the temperature.

In the same conditions, the experiments were performed by nanomagnetic iron oxide as the adsorbent. The obtained results listed in Table 3 show that, Langmuir and Freundlich did not well describe the adsorption isotherm model. The values of $\mathrm{q}_{\max }$ increased by increasing the temperature and also were less than those for magnetically modified activated carbon.

Magnetically modified activated carbon is a perfect and effective adsorbent that offers a fast removal of Crystal Violet from water samples. The kinetic of the adsorption is pseudo second order. Langmuir isotherm can describe well the adsorption model. The sorption capacity and intensity of sorption are enhanced by increasing the temperature. Using nanomagnetic iron oxide as adsorbent compared with magnetically modified activated carbon showed that, it is able to sorption of Crystal Violet with less effectiveness. The previous studies on magnetic adsorbents for removal of Crystal Violet have been presented in Table 4. The time of removal in this study $(10 \mathrm{~min})$ was very short than the contact time in previous studies so that the minimum time of process for these studies with high sorption capacities was $90 \mathrm{~min}$. Thermodynamic and kinetic parameters were not calculated in previous studies. Nanomagnetic iron oxide was not used for removal Crystal Violet previously.
Table 4 The previous studies on magnetic adsorbents to

\begin{tabular}{|c|c|c|}
\hline Adsorbents & $q_{\max }$ & Ref. \\
\hline Magnetic charcoal & $10 \mathrm{mg} \mathrm{cm}^{-3}$ & [23] \\
\hline $\begin{array}{l}\text { Magnetically labeled } \\
\text { Baker's yeast cells }\end{array}$ & $85.9 \mathrm{mg} \mathrm{g}^{-1}$ & [19] \\
\hline $\begin{array}{l}\text { magnetically modified } \\
\text { Saccharomyces cerevisiae } \\
\text { subsp. uvarum cells }\end{array}$ & $41.7 \mathrm{mg} \mathrm{g}^{-1}$ & [24] \\
\hline Ferrofluid modified sawdust & $51.16 \mathrm{mg} \mathrm{g}^{-1}$ & [14] \\
\hline $\begin{array}{l}\text { magnetically modified } \\
\text { Chlorella Vulgaris cells }\end{array}$ & $42.91 \mathrm{mg} \mathrm{g}^{-1}$ & [25] \\
\hline $\begin{array}{l}\text { Magnetic fluid modified } \\
\text { peanut husks }\end{array}$ & $80.9 \mathrm{mg} \mathrm{g}^{-1}$ & {$[17]$} \\
\hline Magnetically modified spent grain & $40.2 \mathrm{mg} \mathrm{g}^{-1}$ & {$[26]$} \\
\hline $\begin{array}{l}\text { Magnetic carbon-iron } \\
\text { oxide nanocomposite }\end{array}$ & $81.70 \mathrm{mg} \mathrm{g}^{-1}$ & {$[20]$} \\
\hline $\begin{array}{l}\text { Magnetically modified } \\
\text { spent coffee grounds }\end{array}$ & $68.1 \mathrm{mg} \mathrm{g}^{-1}$ & [27] \\
\hline $\begin{array}{l}\text { Magnetically modified } \\
\text { activated car bon }\end{array}$ & $67.1 \mathrm{mg} \mathrm{g}^{-1}$ & Present study \\
\hline Nanomagnetic iron oxide & $16.5 \mathrm{mg} \mathrm{g}^{-1}$ & Present study \\
\hline
\end{tabular}
removal Crystal Violet

\section{Conclusion}

The results indicate that magnetically modified activated carbon have considerable potential for the removal of Crystal Violet, also the magnetic adsorbent can be simply removed from solution by using magnet or appropriate magnetic separator after adsorption process. The obtained results of this investigation implicate that this adsorbent was more able to remove dye in the less time with compared to some of studies listed in Table 4. Also we investigated Thermodynamic and kinetic studies for removal process more than other pervious works.

The resulting adsorption capacities demonstrate that, although nanomagnetic iron oxide can be as an adsorbent, but its efficiency is much lower than magnetically modified activated carbon.

\section{Competing interests}

The authors declare that they have no competing interests.

\section{Authors' contributions}

All of the authors have the same contribution. All authors read and approved the final manuscript.

\section{Acknowledgments}

The authors thank the staffs of Payam Noor University of Varamin, specially Mrs. Rezaiee and Mrs. Haj Husseini.

\section{Author details}

${ }^{1}$ Payam Noor University of Varamin, Qarchak, Varamin, Tehran, Iran. ${ }^{2}$ Faculty of Health, Safety and Environment, Shahid Beheshti University of Medical sciences, P. O. Box 16858-116, Tehran, Iran. ${ }^{3}$ Department of Occupational Health Engineering, School of Public Health, Institute for Environmental Research, Tehran University of Medical Sciences, Tehran 14155-6446, Iran. 
Received: 9 July 2014 Accepted: 6 January 2015

Published online: 31 January 2015

\section{References}

1. Banat IM, Nigam P, Singh D, Marchant R. Microbial decolorisation of textile dye containing effluents: a review. Bioresour Technol. 1996;58:217-27.

2. Robinson T, McMullan G, Marchant R, Nigam P. Remediation of dyes in textile effluents: a critical review on current treatment technology with a proposed alternative. Bioresour Technol. 2001;77:247-55.

3. Lee CK, Low KS, Gan PY. Removal of some organic dyes by acid treat spent bleaching earth. Environ Technol. 1999;20:99-104.

4. Hao OJ, Kim H, Chiang PC. Decolorization of wastewater. Environ Sci Technol. 2000;30:449-505.

5. Eiichi l, Ogawa T, Yatome TC, Horisu H. Behavior of activated sludge with dyes. Bull Environ Contam Toxicol. 1985;35:729-34.

6. He H, Yang S, Yu K, Ju Y, Sun C, Wang L. Microwave assisted induced catalytic degradation of crystal violet in nano-nickel dioxide suspensions. J Hazard Mater. 2010;173:393-400.

7. Senthilkumaar S, Kalaamani P, Subburaam CV. Liquid phase adsorption of crystal violet on to activated carbons derived from male flowers of coconut tree. J Hazard Mater. 2006;136:800-8.

8. Garg VK, Gupta R, Yadav AB, Kumar R. Dye removal from aqueous solution by adsorption on treated sawdust. Bioresour Technol. 2003;89:121-4.

9. Mohamed MM. Acid Dye removal: comparison of surfactant modified mesoporous FSM-16 with activated carbon derived from rice husk. J Colloid Interface Sci. 2004;272:28-34.

10. Safarik I, Rego LFT, Mosiniewicz-Szablewska MBE, Weyda F, Safarikova M. New magnetically responsive yeast-based biosorbent for the efficient removal of water-soluble dyes. Enzyme Microb Technol. 2007;40:1551-6.

11. Salem IA. Activation of $\mathrm{H}_{2} \mathrm{O}_{2}$ by Amberlyst-15 resin supported with copper (II)-complexes towards oxidation of crystal violet. Chemosphere. 2001:44:1109-19.

12. Baban A, Yediler A, Lienert D, Kemerdere N, Kettrup A. Ozonation of high strength segregated effluents from a woollen textile dyeing and finishing plant. Dyes Pigments. 2003;58:93-8.

13. Vlyssides AG, Loizidou M, Karlis PK, Zorpas AA, Papaioannou D. Electrochemical oxidation of a textile dye wastewater using a $\mathrm{Pt} / \mathrm{Ti}$ electrode. J Hazard Mater. 1999;B70:41-52.

14. Koyuncu I. Reactive dye removal in dye/salt mixtures by nanofiltration membranes containing vinylsulphone dyes: effects of feed concentration and cross flow velocity. Desalination. 2002;143:243-53.

15. Chen J, Liu M, Zhang J, Ying X, Jin L. Photocatalytic degradation of organic wastes by electrochemically assisted $\mathrm{TiO} 2$ photocatalytic system. J Environ Manage. 2004;70:43-7.

16. Safarikova M, Safarik I. The application of magnetic techniques in biosciences. Magn Electr Sep. 2001;10:223-52.

17. Safarik I, Safarikova M. Magnetic fluid modified peanut husks as an adsorbent for organic dyes removal. Physics Procedia. 2010;9:274-8.

18. Safarik I, Lunackova P, Mosiniewicz-Szablewska E, Weyda F, Safarikova M. Adsorption of water-soluble organic dyes on ferrofluidmodified sawdust. Holzforschung. 2007;61:247-53.

19. Safarik I, Ptackova L, Safarikova M. Adsorption of dyes on magnetically labeled baker's yeast cells. Eur Cells and Mater. 2002;3:52-5.

20. Singh KP, Gupta S, Singh AK, Sinha S. Optimizing adsorption of crystal violet dye from water by magnetic nanocomposite using response surface modeling approach. J Hazard Mater. 2011;186:1462-73.

21. Safarik I, Nymburska K, Safarikova M. Adsorption of water-soluble organic dyes on magnetic Charcoal. J Chem Tech Biotechnol. 1997;69:1-4.

22. Ahmad R. Studies on adsorption of crystal violet dye from aqueous solution onto coniferous pinus bark powder (CPBP). J Hazard Mater. 2009;171:767-73.

23. Porkodi K, Vasanth Kumar K. Equilibrium, kinetics and mechanism modeling and simulation of basic and acid dyes sorption onto jute fiber carbon: Eosin yellow, malachite green and crystal violet single component systems. J Hazard Mater. 2007;143:311-27.

24. Safarikova M, Ptackova L, Kibrikova I, Safarik I. Biosorption of water-soluble dyes on magnetically modified Saccharomyces cerevisiae subsp. uvarum cells. Chemosphere. 2005;59:831-5.
25. Safarikova M, Rainha Pona BM, Mosiniewicz-Szablewska E, Weyda F, Safarik I. Dye adsorption on magnetically modified Chlorella Vulgaris cells. Fresen Environ Bull. 2008;17:486-92.

26. Safarik I, Horska K, Safarikova M. Magnetically modified spent grain for dye removal. J Cereal Sci. 2011;53:78-80.

27. Safarik I, Horska K, Svobodova B, Safarikova M. Magnetically modified spent coffee grounds for dyes removal. Eur Food Res Technol. 2012;234:345-50.

\section{Submit your next manuscript to BioMed Central and take full advantage of:}

- Convenient online submission

- Thorough peer review

- No space constraints or color figure charges

- Immediate publication on acceptance

- Inclusion in PubMed, CAS, Scopus and Google Scholar

- Research which is freely available for redistribution 